\title{
Effect of Beverage Industry Effluent Irrigation on Growth and Yield of Barley
}

\author{
T.S. Punith Raj ${ }^{1 *}$, C.A. Srinivasamurthy ${ }^{2}$, S. Bhaskar $^{3}$, Prabhudev Dhumgond $^{4}$ \\ and S.S. Prakash ${ }^{4}$
}

${ }^{1}$ CGWB, Ministry of Water Resources, Govt. of India, Bhubaneswar, Orissa-751030, India

${ }^{2}$ Director of Research, Central Agricultural University, Imphal, India

${ }^{3}$ Agronomy, Agro-Forestry \& Climate change, ICAR, New Delhi, India

${ }^{4}$ Department of Soil Science and Agricultural Chemistry, CoA, Mandya, India

*Corresponding author

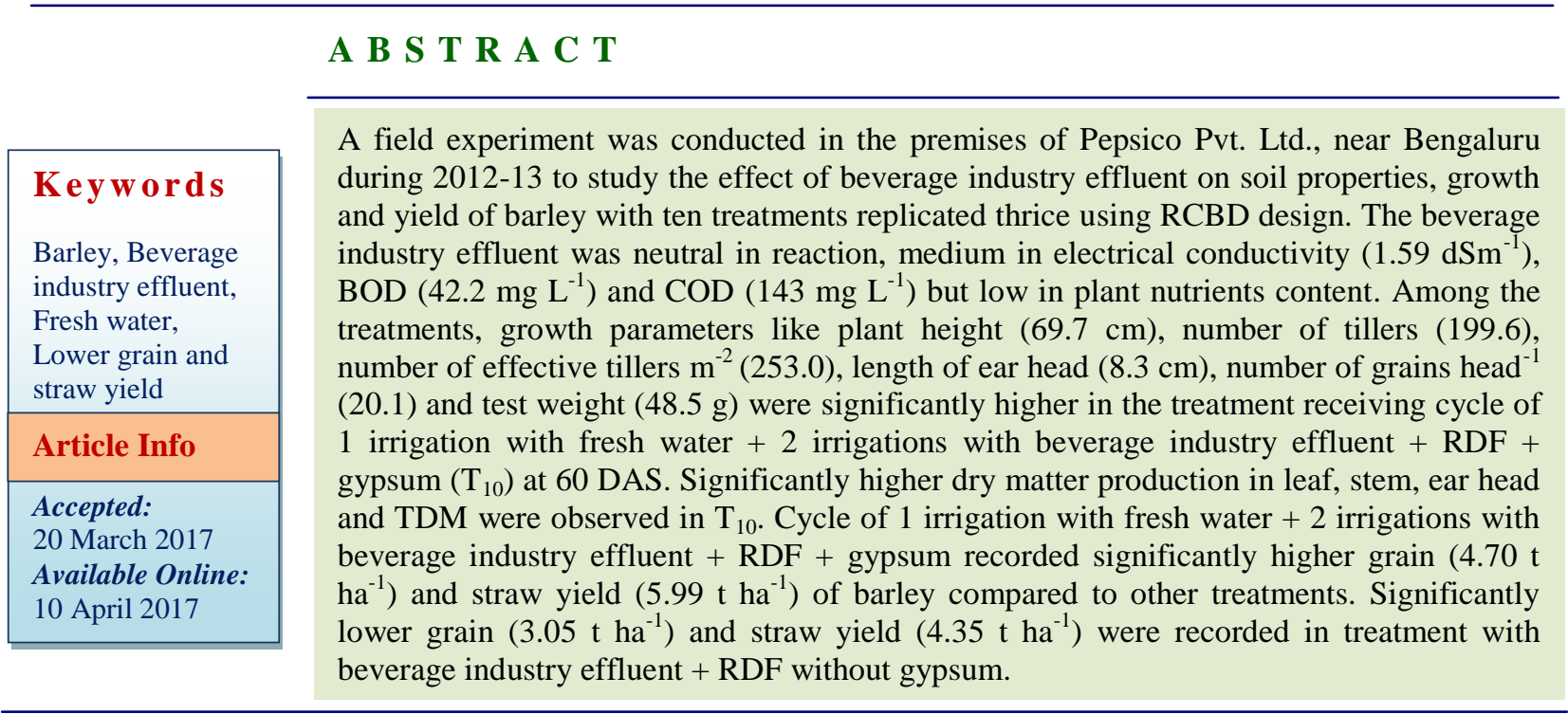

\section{Introduction}

Water, food and energy securities are emerging as increasingly important and vital issues for India and the world. Most of the river basins in India and elsewhere are closing or closed and experiencing moderate to severe water shortages, brought out by the simultaneous effects of agricultural growth, industrialization and urbanization. Current and future fresh water demand could be met by enhancing water use efficiency and demand management. Thus, waste water is emerging as potential source of irrigation after proper treatment.
The Pepsico beverage industry is one of the largest users of water. Even though substantial technological improvements have been made, beverage industry has been producing approximately 650-700 KLD (Kilo litres per day) of effluent. These effluents are produced during different process such as RO reject (135-150 KLD), equipment sanitation (130-150 KLD), final bottle washing (70-80 KLD), floor cleaning (40-50 KLD), filter backwash (120-130 KLD) and domestic activities (15-25 KLD). Agricultural use of treated waste water, therefore, might represent 
a unique opportunity to solve both the problems of water supply for irrigation and disposal of treated waste water at the same time. In developing countries, non-utilization of these effluents has its impact on economic growth and development and there is increased recognition for this potential. Due to increasing environmental concerns and regulations, there have been attempts to utilize this beverage industry effluent in an eco-friendly manner.

Barley (Hordeum vulgare L.) a crop of industrial value ranks fourth in the world acreage and production after rice, wheat and maize. In global acreage, the crop is being cultivated in $55.69 \mathrm{~m}$ ha with a production of $158 \mathrm{mt}$, with average yield potential of $2.44 \mathrm{t}$ ha $^{-1}$ (Anonymous, 2012). Important countries growing this crop are Russia, China, Canada, USA, Spain, France, Australia, United Kingdom and India.

In India, barley is being grown over an area of 7.05 lakh ha with a production of $1.68 \mathrm{mt}$ and productivity of $2.39 \mathrm{t} \mathrm{ha}^{-1}$. It is mainly concentrated in the states of Uttar Pradesh, Punjab, Haryana, Rajasthan and Madhya Pradesh. In Karnataka, barley is grown in typical hot climate characterized by prevalence of high temperature during crop growth. At present, the area under barley is about 3000 ha with a production of 2400 tonnes with an average productivity of $800 \mathrm{~kg}$ $\mathrm{ha}^{-1}$ which is much lower as compared to the national average (1859 $\left.\mathrm{kg} \mathrm{ha}^{-1}\right)$.

\section{Materials and Methods}

Nelamangala is located in Banglore rural district of Eastern Dry Zone, Karnataka and situated at $12^{\circ} 11^{\prime}$ North latitude $76^{\circ} 69^{\prime}$ East longitude with an altitude of 610 meters above mean sea level. A field experiment was carried out during 2012 with 10 different treatments as given in table 1, to know the effect of beverage industry effluent on soil properties, growth and yield of barley. Barley was grown in plots of $3.6 \times 3 \mathrm{~m}^{2}$ size with 3 replications using RCBD design. Beverage industry effluent was collected at 60 days interval from Pepsico Pvt. Ltd., and the samples were analyzed for $\mathrm{pH}$, electrical conductivity, BOD, COD, total solids, total suspended solids, total dissolved solids, total nitrogen, phosphorus, potassium, sodium, calcium, magnesium, chlorides, sulphates and micronutrients $(\mathrm{Zn}, \mathrm{Cu}, \mathrm{Fe}, \mathrm{Mn}$ and $\mathrm{B})$ content by following standard procedures and the average values are presented in table 2.

The calculated quantities of nutrients were added as per recommendations. The quantity of gypsum was calculated on the equivalent basis of sodium $\left(\mathrm{Na}^{+}\right)$content of beverage industry effluent $\left(10.3 \mathrm{~m} . \mathrm{eq} \mathrm{L}^{-1}\right)$ and fresh irrigation water $\left(3.35 \mathrm{~m} . \mathrm{eq} \mathrm{L}^{-1}\right)$. It was applied as basal dose to the treatments $\mathrm{T}_{6}$ to $\mathrm{T}_{10}$ to study the possibilities of overcoming the adverse effect of sodium present in effluent growth and yield of barley. The experiment received 50 per cent of the gypsum required. Based on the irrigation requirement of barley $(\approx 10$ irrigations @ 5 $\mathrm{cm} /$ irrigation) the treatments received cycles of irrigation with fresh water and beverage industry effluent.

The crop was irrigated with fresh water for first 15 days after sowing to avoid the deleterious effect if any of high sodium content of the beverage industry effluent on initial establishment of plants. After 15 days, the crops were imposed with the irrigation treatments as detailed in table 1.

The standard analytical procedures were adopted for soil analysis. The initial soil properties of the experimental site are $\mathrm{pH}$ (7.95), EC (0.53 dS/m), OC (4.6 g/kg), avail$\mathrm{N}(189.6 \mathrm{~kg} / \mathrm{ha}), \mathrm{P}(26.9 \mathrm{~kg} / \mathrm{ha})$ and K (218.8 $\mathrm{kg} / \mathrm{ha})$. 


\section{Results and Discussion}

\section{Plant growth parameters}

In the present study, the results revealed that growth and yield parameters of barley differed significantly due to beverage industry effluent and gypsum (Table 3).

At 30 DAS, the plant height did not vary significantly due to the effect of beverage industry effluent irrigation. Significantly higher plant height during 60 DAS and at harvest (69.7 and $85.2 \mathrm{~cm}$, respectively) was observed with cycle of 1 irrigation with fresh water +2 irrigations with beverage industry effluent $+\mathrm{RDF}+$ gypsum $\left(\mathrm{T}_{10}\right)$ compared to all other treatments followed by the irrigation with beverage industry effluent $+\mathrm{RDF}+$ gypsum $\left(\mathrm{T}_{7}\right)(65.3$ and $78.6 \mathrm{~cm}$, respectively) and irrigation with fresh water + RDF with gypsum $\left(\mathrm{T}_{6}\right)(61.3$ and $74.9 \mathrm{~cm}$, respectively). The treatments $\mathrm{T}_{3}, \mathrm{~T}_{4}(51.2,66.3 \mathrm{~cm}$ and 54.2 , $64.2 \mathrm{~cm}$, respectively) and $\mathrm{T}_{8}, \mathrm{~T}_{9}(58.6,62.3$ $\mathrm{cm}$ and $54,65.6 \mathrm{~cm}$, respectively) were found to be on par with each other. Significantly lower plant height during 60 DAS and at harvest (48.6 and $59.6 \mathrm{~cm}$, respectively) was observed in the treatment receiving irrigation with beverage industry effluent $+\mathrm{RDF}$ without gypsum $\left(\mathrm{T}_{2}\right)$.

\section{Number of leaves}

During different growth stages (30, 60 DAS and at harvest) of barley, the plant did not show any significant difference with respect to number of leaves due to beverage industry effluent irrigation.

\section{Number of tillers}

At 30 DAS, the number of tillers did not show any significant difference due to beverage industry effluent irrigation. Significantly higher number of tillers per $\mathrm{m}^{2}$ were observed during 60 DAS and at harvest (199.6 and 297.4 , respectively) with cycle of 1 irrigation with fresh water +2 irrigations with beverage industry effluent $+\mathrm{RDF}+$ gypsum $\left(\mathrm{T}_{10}\right)$ compared to all other treatments followed by the irrigation with beverage industry effluent $+\mathrm{RDF}+\operatorname{gypsum}\left(\mathrm{T}_{7}\right)$ (186.2 and 252.2, respectively) and irrigation with fresh water + RDF with gypsum $\left(\mathrm{T}_{6}\right)$ (178.6 and 207.8, respectively). The treatments $\mathrm{T}_{3}, \mathrm{~T}_{4}(159.8$, 205 and 149.6, 210.6, respectively) and $\mathrm{T}_{8}, \mathrm{~T}_{9}$ (154.8, 201.8 and 161.5, 224.4, respectively) were found to be on par with each other. Significantly lower plant height at 60 DAS and at harvest (142.8 and 188.6, respectively) was observed in the treatment receiving irrigation with beverage industry effluent + RDF without gypsum $\left(\mathrm{T}_{2}\right)$.

\section{Dry matter accumulation and distribution}

The information on dry matter accumulation and its distribution in leaves, stem, ear head and total dry matter (DM) varied significantly due to beverage industry effluent irrigation at harvest (Table 4).

Significantly higher dry matter production in leaf, stem, ear head and TDM were observed with the treatment receiving cycle of 1 irrigation with fresh water +2 irrigations with beverage industry effluent + RDF + gypsum $\left(\mathrm{T}_{10}\right) \quad(27.8, \quad 52.5, \quad 38.3$ and $118.3 \mathrm{~g}$, respectively) compared to all other treatments followed by the irrigation with beverage industry effluent $+\mathrm{RDF}+$ gypsum $\left(\mathrm{T}_{7}\right)(27.4$, $46.8,36.1$ and $110.5 \mathrm{~g}$, respectively) and irrigation with fresh water + RDF with gypsum $\left(\mathrm{T}_{6}\right)(24.8,45.7,34.4$ and $104.9 \mathrm{~g}$, respectively). Significantly lower dry matter production in leaf, stem, ear head and DM (15.2, 28.3, 20.8 and $64.3 \mathrm{~g}$, respectively) were observed in the treatment which received irrigation of beverage industry effluent + RDF without gypsum $\left(\mathrm{T}_{2}\right)$. 


\section{Yield and yield parameters}

The data pertaining to number of effective tillers $\mathrm{m}^{-2}$, length of ear head, number of grains head ${ }^{-1}$, test weight, grain yield and straw yield as influenced by beverage industry effluent irrigation are presented in table 5 .

Cycle of 1 irrigation with fresh water +2 irrigations with beverage industry effluent + $\mathrm{RDF}+$ gypsum $\left(\mathrm{T}_{10}\right)$ recorded significantly higher number of effective tillers, length of ear head, number of grains head ${ }^{-1}$ and test weight $(253,8.3 \mathrm{~cm}, 20.1$ and $48.5 \mathrm{~g}$, respectively) compared to all other treatments followed by the irrigation with beverage industry effluent $+\mathrm{RDF}+$ gypsum $\left(\mathrm{T}_{7}\right)$ (241.4, $6.7 \mathrm{~cm}, 18.2$ and $37.6 \mathrm{~g}$, respectively) and irrigation with fresh water $+\mathrm{RDF}$ with gypsum $\left(\mathrm{T}_{6}\right)(196.2,6.1 \mathrm{~cm}, 16.3$ and $37.2 \mathrm{~g}$, respectively). The treatments $\mathrm{T}_{3}$ and $\mathrm{T}_{4}$ (340.0, $6.2 \mathrm{~cm}, 15.7,31.5 \mathrm{~g}$ and 85.8, 6.0, $16.0,28.2 \mathrm{~g}$, respectively) were found to be on par with each other. Significantly lower number of effective tillers, length of ear head, number of grains head ${ }^{-1}$ and test weight (160.8, $5.1 \mathrm{~cm}, 14.6$ and $20.8 \mathrm{~g}$, respectively) were observed in the treatment receiving irrigation with beverage industry effluent + RDF without gypsum $\left(\mathrm{T}_{2}\right)$.

The results indicated that higher grain $(4.7 \mathrm{t}$ $\left.\mathrm{ha}^{-1}\right)$ and straw yield (5.99 $\left.\mathrm{t} \mathrm{ha}^{-1}\right)$ were recorded in treatment $T_{10}$ receiving 2 cycles of beverage industry effluent irrigation, 1 cycle of fresh water irrigation, RDF and gypsum followed by irrigation with only beverage industry effluent + RDF and gypsum (4.14 and $5.44 \mathrm{t} \mathrm{ha}^{-1}$ grain, straw yield respectively).

Table.1 Treatment details

\begin{tabular}{|l|l|}
\hline $\mathbf{T}_{\mathbf{1}}$ & Irrigation with fresh water + RDF without gypsum \\
\hline $\mathbf{T}_{\mathbf{2}}$ & Irrigation with beverage industry effluent + RDF without gypsum \\
\hline $\mathbf{T}_{\mathbf{3}}$ & $\begin{array}{l}\text { Alternate irrigation with fresh water and beverage industry effluent }+ \text { RDF without } \\
\text { gypsum }\end{array}$ \\
\hline $\mathbf{T}_{\mathbf{4}}$ & $\begin{array}{l}\text { Cycle of } 2 \text { irrigations with fresh water }+1 \text { irrigation with beverage industry effluent }+ \\
\text { RDF without gypsum }\end{array}$ \\
\hline $\mathbf{T}_{\mathbf{5}}$ & $\begin{array}{l}\text { Cycle of 1 irrigation with fresh water }+2 \text { irrigations with beverage industry effluent }+ \\
\text { RDF without gypsum }\end{array}$ \\
\hline $\mathbf{T}_{\mathbf{6}}$ & Irrigation with fresh water + RDF + gypsum \\
\hline $\mathbf{T}_{\mathbf{7}}$ & Alternate irrigation with fresh water and beverage industry effluent + RDF + gypsum \\
\hline $\mathbf{T}_{\mathbf{8}}$ & $\begin{array}{l}\text { Cycle of } 2 \text { irrigations with fresh water }+1 \text { irrigation with beverage industry effluent }+ \\
\text { RDF + gypsum }\end{array}$ \\
\hline $\mathbf{T}_{\mathbf{9}}$ & $\begin{array}{l}\text { Irrigation with beverage industry effluent + RDF + gypsum } \\
\mathbf{T}_{\mathbf{1 0}}\end{array} \begin{array}{l}\text { Cycle of 1irrigation with fresh water }+2 \text { irrigations with beverage industry effluent }+ \\
\text { RDF + gypsum }\end{array}$ \\
\hline
\end{tabular}


Table.2 Physico-chemical properties of effluent samples

\begin{tabular}{|c|c|c|c|c|c|c|c|c|c|c|c|}
\hline Parameters & Sample-1 & Sample-2 & Sample-3 & Sample-4 & Sample-5 & Sample-6 & Sample-7 & Sample-8 & Sample-9 & Sample-10 & Average \\
\hline $\mathrm{pH}$ & 7.55 & 7.49 & 7.60 & 7.35 & 7.65 & 7.42 & 7.71 & 7.58 & 7.68 & 7.49 & $7.55 \pm 0.1$ \\
\hline $\mathrm{EC}\left(\mathrm{dS} \mathrm{m^{-1 } )}\right.$ & 1.52 & 1.50 & 1.62 & 1.58 & 1.68 & 1.48 & 1.76 & 1.54 & 1.69 & 1.53 & $1.59 \pm 0.1$ \\
\hline BOD $\left(\mathrm{mg} \mathrm{L}^{-1}\right)$ & 46 & 42 & 50 & 39 & 35 & 45 & 36 & 49 & 47 & 33 & $42.2 \pm 6.1$ \\
\hline $\operatorname{COD}\left(\mathrm{mg} \mathrm{L}^{-1}\right)$ & 146 & 149 & 156 & 140 & 145 & 138 & 132 & 150 & 138 & 136 & $143 \pm 7.4$ \\
\hline $\mathrm{DS}\left(\mathrm{g} \mathrm{L}^{-1}\right)$ & 1.75 & 1.91 & 2.0 & 1.86 & 1.95 & 1.72 & 2.10 & 1.92 & 1.95 & 1.98 & $1.91 \pm 0.1$ \\
\hline $\mathrm{TSS}\left(\mathrm{g} \mathrm{L}^{-1}\right)$ & 1.57 & 1.56 & 1.52 & 1.63 & 1.45 & 1.50 & 1.64 & 1.70 & 1.63 & 1.60 & $1.5 \pm 0.1$ \\
\hline $\mathrm{TS}\left(\mathrm{g} \mathrm{L}^{-1}\right)$ & 3.26 & 3.39 & 3.3 & 3.48 & 3.31 & 3.25 & 3.81 & 3.70 & 3.56 & 3.58 & $3.46 \pm 0.2$ \\
\hline $\mathrm{Na}\left(\mathrm{m} . \mathrm{eq} \mathrm{L} \mathrm{L}^{-1}\right)$ & 9.6 & 10.4 & 10.3 & 9.4 & 10.8 & 9.5 & 10.5 & 9.8 & 11.6 & 10.9 & $10.3 \pm 0.7$ \\
\hline $\mathrm{CO}_{3}\left(\mathrm{~m} . \mathrm{eq} \mathrm{L} \mathrm{L}^{-1}\right)$ & nil & nil & nil & nil & nil & nil & nil & nil & nil & Nil & Nil \\
\hline $\mathrm{HCO}_{3}\left(\mathrm{~m}\right.$. eq L $\left.{ }^{-1}\right)$ & 6.9 & 6.4 & 6.6 & 6.8 & 6.7 & 6.7 & 7.1 & 7.0 & 7.2 & 6.9 & $6.8 \pm 0.2$ \\
\hline Total-N (mg L $\left.{ }^{-1}\right)$ & $*$ & $*$ & $*$ & $*$ & $*$ & $*$ & $*$ & $*$ & $*$ & $*$ & $*$ \\
\hline Total-P $\left(\mathrm{mg} \mathrm{L}^{-1}\right)$ & 2 & 1.8 & 2.3 & 1.6 & 1.7 & 1.5 & 1.9 & 2.1 & 2.3 & 2.8 & $2.0 \pm 0.4$ \\
\hline Total-K $\left(\mathrm{mg} \mathrm{L}^{-1}\right)$ & 30 & 31 & 34 & 28 & 35 & 30 & 34 & 25 & 38 & 45 & $33 \pm 5.6$ \\
\hline Total-S (mg L $\left.{ }^{-1}\right)$ & 150 & 152 & 135 & 146 & 132 & 140 & 155 & 138 & 163 & 159 & $147 \pm 10.5$ \\
\hline $\mathrm{Ca}\left(\mathrm{m} . \mathrm{eq} \mathrm{L} \mathrm{L}^{-1}\right)$ & 3.70 & 3.40 & 3.45 & 3.63 & 3.56 & 3.82 & 3.78 & 3.94 & 3.95 & 3.45 & $3.67 \pm 0.2$ \\
\hline $\mathrm{Mg}\left(\mathrm{m} . \mathrm{eq} \mathrm{L} \mathrm{L}^{-1}\right)$ & 2.60 & 2.50 & 2.68 & 2.62 & 2.52 & 2.35 & 2.78 & 2.60 & 2.30 & 2.10 & $2.51 \pm 0.2$ \\
\hline $\mathrm{Cl}\left(\mathrm{m} . \mathrm{eq} \mathrm{L} \mathrm{L}^{-1}\right)$ & 7.7 & 7.5 & 7.6 & 7.3 & 7.0 & 7.2 & 7.4 & 7.5 & 8.9 & 7.8 & $7.5 \pm 0.5$ \\
\hline $\mathrm{Fe}\left(\mathrm{mg} \mathrm{L}^{-1}\right)$ & nil & nil & nil & nil & nil & nil & nil & nil & nil & nil & Nil \\
\hline $\mathrm{Cu}\left(\mathrm{mg} \mathrm{L}^{-1}\right)$ & nil & nil & nil & nil & nil & nil & nil & nil & nil & nil & Nil \\
\hline $\mathrm{Mn}\left(\mathrm{mg} \mathrm{L}^{-1}\right)$ & nil & nil & nil & nil & nil & nil & nil & nil & nil & nil & Nil \\
\hline $\mathrm{Zn}\left(\mathrm{mg} \mathrm{L}^{-1}\right)$ & nil & nil & nil & nil & nil & nil & nil & nil & nil & nil & Nil \\
\hline $\mathrm{B}\left(\mathrm{mg} \mathrm{L}^{-1}\right)$ & nil & nil & nil & nil & nil & nil & nil & nil & nil & nil & Nil \\
\hline SAR & 5.6 & 6.2 & 6.1 & 5.2 & 6.3 & 5.6 & 5.8 & 5.4 & 6.8 & 6.8 & $6.0 \pm 0.6$ \\
\hline $\operatorname{RSC}\left(\right.$ m.eq L $\left.{ }^{-1}\right)$ & 0.60 & 0.50 & 0.47 & 0.55 & 0.64 & 0.53 & 0.54 & 0.46 & 0.95 & 1.35 & $0.66 \pm 0.3$ \\
\hline \multicolumn{12}{|c|}{ Note: $*$ indicates traces found that could not be detected } \\
\hline \multicolumn{12}{|c|}{ Sodium content of fresh water } \\
\hline $\mathrm{Na}\left(\mathrm{m} . \mathrm{eq} \mathrm{L} \mathrm{L}^{-1}\right)$ & 3.3 & 3.5 & 3.0 & 3.2 & 3.5 & 3.1 & 3.7 & 3.4 & 3.3 & 3.0 & $3.3 \pm 0.2$ \\
\hline
\end{tabular}


Table.3 Effect of beverage industry effluent irrigation on plant height, number of leaves and number of tillers of barley

\begin{tabular}{|c|c|c|c|c|c|c|c|c|c|}
\hline \multirow[b]{2}{*}{ Treatments } & \multicolumn{3}{|c|}{ Plant height (cm) } & \multicolumn{3}{|c|}{ Number of leaves } & \multicolumn{3}{|c|}{ Number of tillers $\mathbf{m}^{-2}$} \\
\hline & 30 DAS & 60 DAS & $\begin{array}{c}\text { At } \\
\text { harvest }\end{array}$ & 30 DAS & 60 DAS & $\begin{array}{c}\text { At } \\
\text { harvest }\end{array}$ & 30 DAS & 60 DAS & $\begin{array}{c}\text { At } \\
\text { harvest }\end{array}$ \\
\hline $\mathbf{T}_{1}$ & 20.7 & 56.8 & 71.3 & 2.4 & 5.1 & 6.1 & 43.4 & 173.0 & 231.4 \\
\hline $\mathbf{T}_{2}$ & 22.6 & 48.6 & 59.6 & 3.1 & 5.0 & 6.3 & 42.0 & 142.8 & 188.6 \\
\hline $\mathbf{T}_{\mathbf{3}}$ & 18.7 & 51.2 & 66.3 & 2.5 & 6.0 & 7.2 & 41.6 & 159.8 & 205.0 \\
\hline $\mathbf{T}_{4}$ & 23.9 & 54.2 & 64.2 & 2.7 & 5.3 & 6.4 & 41.0 & 149.6 & 210.6 \\
\hline $\mathbf{T}_{5}$ & 21.5 & 49.6 & 62.3 & 2.3 & 6.0 & 7.3 & 40.6 & 156.2 & 218.4 \\
\hline$T_{6}$ & 23.8 & 61.3 & 74.9 & 3.5 & 6.1 & 7.4 & 44.4 & 178.6 & 207.8 \\
\hline $\mathbf{T}_{7}$ & 22.1 & 65.3 & 78.6 & 3.3 & 5.1 & 6.8 & 43.8 & 186.2 & 252.2 \\
\hline $\mathbf{T}_{8}$ & 22.9 & 58.6 & 62.3 & 3.4 & 5.5 & 6.5 & 42.0 & 154.8 & 201.8 \\
\hline $\mathbf{T}_{9}$ & 24.5 & 54.0 & 65.6 & 3.5 & 5.6 & 7.2 & 44.2 & 161.2 & 224.4 \\
\hline $\mathbf{T}_{10}$ & 21.5 & 69.7 & 85.2 & 3.5 & 6.2 & 7.9 & 43.8 & 199.6 & 297.4 \\
\hline S. Em \pm & 1.10 & 1.76 & 2.1 & 0.23 & 0.30 & 0.37 & 0.68 & 2.54 & 5.7 \\
\hline C. D. at $5 \%$ & NS & 5.25 & 6.45 & NS & NS & NS & NS & 7.54 & 17.0 \\
\hline CV (\%) & 5.6 & 5.3 & 5.4 & 9.1 & 9.3 & 9.3 & 5.5 & 5.3 & 8.9 \\
\hline
\end{tabular}

\section{Legend:}

$\mathrm{T}_{1}$ : Irrigation with fresh water $+\mathrm{RDF}$ without gypsum

$\mathrm{T}_{2}$ : Irrigation with beverage industry effluent $+\mathrm{RDF}$ without gypsum

$\mathrm{T}_{3}$ : Alternate irrigation with fresh water and beverage industry effluent + RDF without gypsum

$\mathrm{T}_{4}$ : Cycle of 2 irrigations with fresh water +1 irrigation with beverage industry effluent $+\mathrm{RDF}$ without gypsum

$\mathrm{T}_{5}$ : Cycle of 1 irrigation with fresh water +2 irrigations with beverage industry effluent $+\mathrm{RDF}$ without gypsum
$\mathrm{T}_{6}$ : Irrigation with fresh water $+\mathrm{RDF}+$ gypsum

$\mathrm{T}_{7}$ : Irrigation with beverage industry effluent $+\mathrm{RDF}+$ gypsum

$\mathrm{T}_{8}$ : Alternate irrigation with fresh water and beverage industry effluent + RDF + gypsum

$\mathrm{T}_{9}$ : Cycle of 2 irrigations with fresh water +1 irrigation with beverage industry effluent $+\mathrm{RDF}+$ gypsum

$\mathrm{T}_{10}$ : Cycle of 1 irrigation with fresh water +2 irrigations with beverage industry effluent + RDF + gypsum

FYM@ $7.5 \mathrm{tha}^{-1}$ common for all the treatments 
Table.4 Effect of beverage industry effluent irrigation on dry matter accumulation of barley

\section{Legend:}

\begin{tabular}{|c|c|c|c|c|}
\hline \multirow{2}{*}{ Treatments } & \multicolumn{4}{|c|}{ Dry matter accumulation (g) } \\
\cline { 2 - 5 } & Leaf & Stem & $\begin{array}{c}\text { Ear } \\
\text { head }\end{array}$ & TDM \\
\hline $\mathbf{T}_{\mathbf{1}}$ & 22.2 & 43.1 & 32.6 & 97.9 \\
\hline $\mathbf{T}_{\mathbf{2}}$ & 15.2 & 28.3 & 20.8 & 64.3 \\
\hline $\mathbf{T}_{\mathbf{3}}$ & 17.9 & 34.3 & 26.8 & 79.0 \\
\hline $\mathbf{T}_{\mathbf{4}}$ & 19.7 & 37.9 & 28.1 & 85.7 \\
\hline $\mathbf{T}_{\mathbf{5}}$ & 15.5 & 32.5 & 23.2 & 71.2 \\
\hline $\mathbf{T}_{\mathbf{6}}$ & 24.8 & 45.7 & 34.4 & 104.9 \\
\hline $\mathbf{T}_{\mathbf{7}}$ & 27.4 & 46.8 & 36.1 & 110.5 \\
\hline $\mathbf{T}_{\mathbf{8}}$ & 21.7 & 41.6 & 30.5 & 93.8 \\
\hline $\mathbf{T}_{\mathbf{9}}$ & 22.1 & 43.2 & 32.2 & 97.5 \\
\hline $\mathbf{T}_{\mathbf{1 0}}$ & 27.8 & 52.5 & 38.3 & 118.3 \\
\hline S. Em $\mathbf{E}$ & $\mathbf{1 . 0 8}$ & $\mathbf{0 . 8 1}$ & $\mathbf{0 . 6 4}$ & $\mathbf{1 . 5 1}$ \\
\hline C. D. at 5\% & $\mathbf{3 . 2 0}$ & $\mathbf{2 . 4 0}$ & $\mathbf{1 . 9 0}$ & $\mathbf{4 . 5 2}$ \\
\hline CV $\mathbf{( \% )}$ & $\mathbf{8 . 7}$ & $\mathbf{3 . 4}$ & $\mathbf{3 . 6}$ & $\mathbf{2 . 8}$ \\
\hline & \multicolumn{5}{|c}{ Note: TDM-Total dry matter } \\
\hline
\end{tabular}

$\mathrm{T}_{1}$ : Irrigation with fresh water $+\mathrm{RDF}$ without gypsum

$\mathrm{T}_{2}$ : Irrigation with beverage industry effluent $+\mathrm{RDF}$ without gypsum

$\mathrm{T}_{3}$ : Alternate irrigation with fresh water and beverage industry effluent + RDF without gypsum

$\mathrm{T}_{4}$ : Cycle of 2 irrigations with fresh water +1 irrigation with beverage industry effluent + RDF without gypsum

$\mathrm{T}_{5}$ : Cycle of 1 irrigation with fresh water +2 irrigations with beverage industry effluent + RDF without gypsum
$\mathrm{T}_{6}$ : Irrigation with fresh water $+\mathrm{RDF}+$ gypsum

$\mathrm{T}_{7}$ : Irrigation with beverage industry effluent $+\mathrm{RDF}+$ gypsum

$\mathrm{T}_{8}$ : Alternate irrigation with fresh water and beverage industry effluent + RDF + gypsum

$\mathrm{T}_{9}$ : Cycle of 2 irrigations with fresh water +1 irrigation with beverage industry effluent $+\mathrm{RDF}+$ gypsum

$\mathrm{T}_{10}$ : Cycle of 1 irrigation with fresh water +2 irrigations with beverage industry effluent $+\mathrm{RDF}+$ gypsum

FYM@ $7.5 \mathrm{t} \mathrm{ha}^{-1}$ and borax @ $10 \mathrm{~kg} \mathrm{ha}^{-1}$ common for all the treatments 
Table.5 Effect of beverage industry effluent irrigation on yield parameters and yield of barley

\begin{tabular}{|c|c|c|c|c|c|c|}
\hline \multirow[b]{2}{*}{ Treatments } & \multicolumn{4}{|c|}{ Yield parameters } & \multicolumn{2}{|c|}{ Yield } \\
\hline & $\begin{array}{c}\text { Number of } \\
\text { effective tillers } \\
\mathbf{m}^{-2}\end{array}$ & $\begin{array}{l}\text { Length of } \\
\text { ear head } \\
(\mathrm{cm})\end{array}$ & $\begin{array}{c}\text { No. of } \\
\text { grains } \\
\text { per ear } \\
\text { head }\end{array}$ & $\begin{array}{c}\text { Test } \\
\text { weight } \\
\text { (g) }\end{array}$ & $\begin{array}{l}\text { Grain } \\
\text { yield } \\
\left(\mathbf{t ~ h a}^{-1}\right)\end{array}$ & $\begin{array}{c}\text { Straw } \\
\text { yield } \\
\left(\mathbf{t ~ h a}^{-1}\right)\end{array}$ \\
\hline $\mathbf{T}_{1}$ & 166.6 & 7.5 & 17.5 & 34.1 & 3.55 & 5.24 \\
\hline $\mathbf{T}_{2}$ & 160.8 & 5.1 & 14.6 & 20.8 & 3.05 & 4.35 \\
\hline $\mathbf{T}_{3}$ & 171.2 & 6.2 & 15.7 & 31.5 & 3.39 & 4.68 \\
\hline $\mathbf{T}_{4}$ & 171.6 & 6.0 & 16.0 & 28.2 & 3.45 & 4.76 \\
\hline $\mathbf{T}_{5}$ & 194.6 & 5.6 & 15.4 & 25.8 & 3.29 & 4.59 \\
\hline$T_{6}$ & 196.2 & 6.1 & 16.3 & 37.2 & 3.94 & 4.85 \\
\hline $\mathbf{T}_{7}$ & 241.4 & 6.7 & 18.2 & 37.6 & 4.14 & 5.44 \\
\hline $\mathbf{T}_{8}$ & 182.2 & 6.9 & 17.0 & 39.6 & 3.77 & 5.07 \\
\hline $\mathbf{T}_{9}$ & 195.8 & 6.5 & 15.9 & 30.8 & 3.44 & 4.74 \\
\hline $\mathbf{T}_{10}$ & 253.0 & 8.3 & 20.1 & 48.5 & 4.70 & 5.99 \\
\hline S. Em \pm & 9.34 & 0.09 & 0.49 & 0.99 & 0.11 & 0.15 \\
\hline C. D. at $5 \%$ & 27.32 & 0.25 & 1.46 & 2.94 & 0.34 & 0.44 \\
\hline $\mathrm{CV}(\%)$ & 8.3 & 2.2 & 5.1 & 5.13 & 5.11 & 5.13 \\
\hline
\end{tabular}

\section{Legend:}

$\mathrm{T}_{1}$ : Irrigation with fresh water + RDF without gypsum

$\mathrm{T}_{2}$ : Irrigation with beverage industry effluent $+\mathrm{RDF}$ without gypsum

$\mathrm{T}_{3}$ : Alternate irrigation with fresh water and beverage industry effluent + RDF without gypsum

$\mathrm{T}_{4}$ : Cycle of 2 irrigations with fresh water +1 irrigation with beverage industry effluent + RDF without gypsum

$\mathrm{T}_{5}$ : Cycle of 1 irrigation with fresh water +2 irrigations with beverage industry effluent + RDF without gypsum
$\mathrm{T}_{6}$ : Irrigation with fresh water $+\mathrm{RDF}+$ gypsum

$\mathrm{T}_{7}$ : Irrigation with beverage industry effluent $+\mathrm{RDF}+$ gypsum

$\mathrm{T}_{8}$ : Alternate irrigation with fresh water and beverage industry effluent $+\mathrm{RDF}+$ gypsum

$\mathrm{T}_{9}$ : Cycle of 2 irrigations with fresh water +1 irrigation with beverage industry effluent $+\mathrm{RDF}+$ gypsum

$\mathrm{T}_{10}$ : Cycle of 1 irrigation with fresh water +2 irrigations with beverage industry effluent + RDF + gypsum

FYM@ $7.5 \mathrm{t} \mathrm{ha}^{-1}$ and borax @ $10 \mathrm{~kg} \mathrm{ha}^{-1}$ common for all the treatments 
The effect of treatment $\mathrm{T}_{1}$ (Irrigation with fresh water + RDF without gypsum) and $T_{7}$ (Irrigation with beverage industry effluent + $\mathrm{RDF}+$ gypsum) on yield of barley were on par with each other. The lower yield of barley (3.05 and $4.35 \mathrm{t} \mathrm{ha}^{-1}$ grain, straw yield respectively) was observed in the treatment receiving only beverage industry effluent + RDF, without gypsum when compared to others. Gypsum had significant effect in increasing the yield of the crop by reducing the effect of sodium on crop growth.

In the present study, the results revealed that growth and yield parameters of barley differed significantly due to beverage industry effluent and gypsum. However, significantly higher plant height, number of tillers, number of effective tillers $\mathrm{m}^{-2}$, length of ear head, number of grains head ${ }^{-1}$, test weight, grain yield and straw yield was observed in the treatment receiving cycle of 1 irrigation with fresh water +2 irrigations with beverage industry effluent + RDF + gypsum $\left(T_{10}\right)$ compared to all other treatments followed by the irrigation with beverage industry effluent $+\mathrm{RDF}+$ gypsum $\left(\mathrm{T}_{7}\right)$ and irrigation with fresh water + RDF with gypsum $\left(T_{6}\right)$. This might be due to addition of small amount of nutrients from beverage industry effluent and gypsum as an amendment which are required for plant growth and development. Positive effect on growth and yield parameters due to combined use of effluent irrigation and amendments on cumbunapier grass, maize and sunflower were reported by Parameswari (2009). Similar results were reported by Anoop et al., (2002) and Vanitha (2010).

Increase in grain yield of barleyin the treatment $T_{10}$ receiving cycle of 1 irrigation with fresh water +2 irrigations with beverage industry effluent + RDF + gypsum $\left(4.70 \mathrm{t} \mathrm{ha}^{-1}\right)$ followed by irrigation with only beverage industry effluent + RDF and gypsum (4.14 $\left.\mathrm{t} \mathrm{ha}^{-1}\right)$. Similar results were observed by Anonymous
(2008) who reported that among coffee pulp effluent irrigated treatments, irrigation with 2:1 cycles of lime treated coffee pulp effluent and fresh water recorded significantly higher baby corn yield (98.2 $\mathrm{q} \mathrm{ha}^{-1}$ and $26.67 \mathrm{t} \mathrm{ha}^{-1}$ ) which was on par with alternate irrigation with fresh water and lime treated coffee pulp effluent (77.6 q ha ${ }^{-1}$ ) during 2006. Whereas, in 2007, alternate irrigation fresh water and lime treated coffee pulp effluent recorded significantly higher baby corn yield (102.9 $\mathrm{qha}^{-1}$ ) over other effluent irrigated treatments.

This was mainly due to higher plant height, number of tillers, number of effective tillers $\mathrm{m}^{-2}$, length of ear head, number of grains head $^{-1}$ and test weightobserved in this treatment. These results are in conformity with the findings of Pandey (2006), Efstathios et al., (2009), Moazzam et al., (2010) and Nwoko (2010) who reported increased yields due to more growth parameters and yield parameters with application of waste water to field crops. Devarajan and Oblisamy (1995) recorded the highest cane yield of $182.8 \mathrm{t} \mathrm{ha}^{-1}$ due to irrigation with distillery effluent diluted 50 times. Best results were obtained when 50 times diluted vinasse was applied at $16 \mathrm{t} \mathrm{ha}^{-1}$ (Ghugare and Magar, 1995). Pujar (1995) recorded highest grain yield of wheat at 50 times and maize at 10 times dilution of effluent irrigation. Twelve pre-sowing irrigations with the distillery effluent had no adverse effect on the germination of maize but improved the growth and yield (Singh and Raj Bahadur, 1998). Pujar (1995) registered highest sugar cane yield with 10 times dilution when distillery effluent was amended along with pressmud.

Higher grain and straw yield of barley in the present study could be attributed to better total uptake of essential nutrients and its translocation to economic parts as well as improvement in yield attributing characters like number of tillers, number of effective 
tillers $\mathrm{m}^{-2}$ and length of ear head. These results are in conformity with the findings of Parameswari (2009).

Significantly lower growth and yield of barley was recorded in treatment receiving irrigation with beverage industry effluent $+\mathrm{RDF}$ without gypsum which may be attributed to accumulation of salts in the root zone and the presence of sodium and chlorides in irrigation water which are absorbed by plants and accumulate in the leaves. However, lower yield of barley (3.05 and $4.35 \mathrm{t} \mathrm{ha}^{-1}$ grain, straw yield respectively) was observed in the treatment receiving only beverage industry effluent + RDF, without gypsum when compared to others. These effects might be due to the salinity through brewery waste water irrigation which generally inhibited the growth, yield attributes and yield through reduced water absorption, reduced metabolic activities due to $\mathrm{Na}^{+}$and $\mathrm{Cl}^{-}$toxicity and nutrients deficiency caused by ionic interference. These results are in agreement with findings of Leth and Burrow (2002), Mohamedin et al., (2006) and Parameswari (2009).

Based on the results of field trial, it can be concluded that, barley crop performed well under beverage industry effluent irrigation in presence of gypsum. The continuous use of beverage industry effluent for several years may lead to a salinity buildup, as well as contribute to the deterioration of soil quality and results in lower growth and yield of crops. But in T. Begur, Nelamangala region due to the even distribution of rain, one season crop might be under rainfed condition which might dilute the pollutants and be utilized during the next cropping season. This problem could be effectively managed by the use of gypsum. However, long term field experiments in different agro-climatic zones involving use of different amendments are needed for confirmatory results on this regard.

\section{Acknowledgement}

I am extremely grateful to Pepsico Pvt. Ltd., and its staff members for their precious support in successful completion my field experiments at Nelamangalataluk, Bengaluru. I express my sincere gratitude to University of Agricultural Sciences, Bangalore for all the facility.

\section{References}

Anonymous, 2008, Final Report of Coffee Board (GOI), Utilization of coffee processing wastes in agriculture and its environmental impact. Dept. of Agronomy, University of Agricultural Science, Bengaluru, India.

Anonymous, 2012, Ministry of Agriculture, Government of India, http/India stat.dom.

Anoop, S., Agrawal, S. B., Rai, J. P. N. and Pratibha, S., 2002. Assessment of the pulp and paper mill effluent on growth, yield and nutrient quality of wheat (Triticum aestivum). J. Environ. Biol., 28(3): 283-288.

Devarajan, L. and Oblisamy, G., 1995, Effect of distillery effluent on soil properties, yield and quality of sugarcane. Madras Agric. J., 82: 397-399.

Efstathios, T., Martha, L., Ioannis, P., Thomas, S., Fokion, P., Maria, T. and Paraskevi, M., george, V., 2009, The effect of treated urban wastewater on soil properties, plant tissue composition and biomass productivity in berseem clover and corn. J. Food Agric. Envt., 7(3-4): 782-786.

Ghugare, R. V. and Magar, S. S., 1995, Effect of alcohol distillery effluent (spent wash) on yield and quality of Adsali sugarcane (Co-740) in Vertisol. Bharatiya Sugar., 22: 97-98.

Leth, M. and Burrow, D., 2002, Effects of irrigating with saline water on soil 
structure in the shepparton irrigation region. Department of resource and environment report. Victoria University., pp. 192.

Moazzam, A. S., Shahid, S., Omme, H. and Suriya, J., 2010, Irrigation of sorghum crop with waste stabilization pond effluent: growth and yield responses. Pakistan J. Bot., 42(3): 1665-1674.

Mohamedin, A. A. M., Abd El-kader and Badran, N. M., 2006, Response of sunflower (Helianthus annuus L.) to plants salt stress under different water table depths. J. Appl. Sci. Res., 2(12): 1175-1184.

Nwoko, C. O., 2010, Evaluation of palm oil mill effluent to maize (Zea mays. L) crop yield, tissue nutrient content and residual soil chemical properties. Australian J. Crop Sci., 23(1): 56-62.

Pandey, S. N., 2006, Effect of brewery effluent on seedlings of Cajanus cajan and Vigra mungo. J. Appl. Bio-sci., 32(1): 199-122.
Parameswari, E., 2009, Impact of agricultural drainage water on crops under sequential biological concentration system and use of nanoparticles for wastewater treatment. Ph.D., thesis, submitted to Tamil Nadu Agricultural University, Coimbatore.

Pujar, S. S., 1995, Effect of distillery effluent irrigation on growth, yield and quality of crops. M.Sc. (Agri.) Thesis, University of Agricultural Sciences, Dharwad.

Singh, Y. and Raj Bahadur, 1998, Effect of application of distillery effluent on maize (Zea mays) crop and soil properties. Indian J. Agric. Sci., 68: $70-74$.

Vanitha, B., 2010, Influence of spent wash on nutrient mineralization and crop productivity Ph.D. Thesis submitted to Tamil nadu Agricultural University, Coimbatore.

\section{How to cite this article:}

Punith Raj T.S., C.A. Srinivasamurthy, S. Bhaskar and Prabhudev Dhumgond and Prakash, S.S. 2017. Effect of Beverage Industry Effluent Irrigation on Growth and Yield of Barley. Int.J.Curr.Microbiol.App.Sci. 6(4): 2403-2413. doi: https://doi.org/10.20546/ijcmas.2017.604.280 